\title{
Corporate Social Responsibility in a Local Subsidiary: Internal and External Stakeholders’ Power
}

\begin{abstract}
Purpose: Using a theoretical and empirical focus on the power stakeholders exert, this exploratory study aims to provide a better understanding of the factors that influence the subsidiaries of multinationals' participation in Corporate Social Responsibility (CSR) under the pressures (expectations and demands) their complex system of internal and external stakeholders’ places upon them.

Design/Methodology/Approach: Using an in-depth case study, the relationship a local subsidiary in the food and beverage industry has with its stakeholders as regards CSR is analysed.

Findings: The findings illustrate three main aspects: i) how the local company is affected by and how it affects its stakeholders (an example of the multidirectionality of power and influence); ii) the direct and indirect practices that are adopted to address challenges; and iii) the importance of the role the local subsidiary plays as an implementer and diffuser of its parent organization's responsible practices across the industry value chain.
\end{abstract}

Originality: To the best of our knowledge, our focus on analysing the power stakeholders have in the context of multinational companies has not been applied before, and the outcome of using this approach is that we have uncovered gaps in the literature for future research.

Keywords: stakeholder; stakeholder power; local subsidiary; environment; corporate social responsibility

Type: Research paper 


\section{Introduction}

Corporate social responsibility (CSR) has recently surfaced as a crucial aspect of organizations and companies are becoming increasingly interested in CSR practices as strategic tools that can have a considerable impact on their perceived image (Jones et al., 2007; Shams, 2016), their legitimacy (Jakhar, 2017; Mohammed, 2013; Surroca et al., 2013) and performance (Ayuso et al., 2014; Salehi et al., 2018). CSR is also seen as a way to increase their competitive advantage (Jakhar, 2017) and discover new sources of value creation (Mohammed, 2013). At the same time, however, how to integrate CSR into day-to-day practices in terms of being compatible with the organization's culture (Chatzoglou et al., 2017), how to reconcile the internal organization of CSR with an adequate response to stakeholder demands (Ayuso et al., 2014; Di Bella and AlFayoumi, 2016; Zhao et al., 2014), and how to find the balance between short- and long-term impacts or gains (Wu, et al., 2013), are still unanswered questions.

CSR has several definitions (see e.g., Dahlsrud, 2008) but this paper chooses to define it in the same way the Commission of the European Communities (2001) does, i.e., " $a$ concept whereby companies integrate social and environmental concerns into their business operations and into their interaction with their stakeholders on a voluntary basis” (Rodríguez Bolívar et al., 2015).

Multinational companies (MNCs) are a good context in which to study CSR because they manage portfolios of national entities (Bartlett and Ghoshal, 2002). For example, the arguably asymmetric CSR behaviour at home (headquarters) and in the host countries (subsidiaries) has been analysed and the conclusion drawn that the transfer of CSR practices to subsidiaries can be positive (Jamali, 2010) or negative due to transferring less responsible behaviour to overseas subsidiaries (Surroca et al., 2013). In turn, subsidiaries are crucial players in MNCs because they are considered as valueadding entities in a host country (Birkinshaw, 1998). Local responsiveness in CSR is a particularly difficult challenge (Barin Cruz and Boehe, 2010; Bondy and Starkey, 2014) because the CSR practices in MNC subsidiaries often have contradictory interests when it comes to their stakeholders (Park and Choi, 2015), not least because they have a wider variety of them (Zhao et al., 2014), for instance, not only stakeholders at the local (host) level, but also those from the home country. This reality requires an increased effort to identify and prioritize stakeholder characteristics and demands that pressure subsidiaries to become (or not) engaged in CSR (Campbell et al., 2012; Gifford et al., 2010). Subsidiaries are part of a business hierarchy and, as such, should also respond to 
the expectations and demands of their internal stakeholders. Hence, when it comes to practicing CSR, an MNC subsidiary will define strategies and actions to manage stakeholder demands. Some of these will be directly adopted from the host country and others will be developed adhoc to fit local demand and pursue social adaptation (Zhao et al. 2014). To this effect, van Alstine (2009) argues that CSR practices are diffused between two levels, headquarters and national, but he does not consider a possible lower level, i.e., the 'local subsidiary'. In fact, apart from some notable exceptions (e.g., Zhao et al. 2014), localization aspects in the CSR activities of MNCs have not been afforded systematic attention in the literature and the potential determinants of specific subsidiary strategies remain largely unexplored (Jamali, 2010).

Despite substantial research efforts, some authors still argue that there is a lack of theoretical consensus as to how MNCs should implement CSR to build the legitimacy required (Hah and Freeman, 2014; Surroca et al., 2013) to thrive in the host country. For example, some recent research addressing CSR dilemmas for MNCs highlights the need for the views of local subsidiaries and their decision-making processes to be taken into consideration (Bondy and Starkey, 2014). This analysis contributes to the open call for more research into understanding why companies respond differently to stakeholder pressure (Delmas and Toffel, 2008; Jakhar, 2017). In this vein, some authors suggest that differential performance is linked to strategic and organizational orientation (Ardito and Dangelico, 2018), whereas others point to the pressure stakeholders exert and/or the internal resources and capabilities as mediators firms have (Jakhar, 2017), or the role that developing dynamic capabilities to meet sustainable corporate growth plays (Wu et al., 2013).

To contribute to this debate and provide a different angle to address the call for more research into these issues, we ask how and why internal and external stakeholders influence CSR practices in local subsidiaries (e.g., Delmas and Toffel, 2008; Hah and Freeman, 2014; Jamali, 2010; Surroca et al., 2013; Bondy and Starkey, 2014). To answer this, we focus on stakeholder power theory (e.g., Frooman, 1999; Mitchell et al., 1997; Agle et al., 1999; Tang and Tang, 2012). Accordingly, we analyse the power balance between the different internal and external stakeholders and how this influences the actions taken by organizations and, in turn, some stakeholders. For example, opinions differ as to whether MNCs should stimulate centralized CSR strategies or whether they should develop them locally in consultation with stakeholders (Muller, 2006). Analysing power balances can also help explain the rationale behind different 
potential strategies. To the best of our knowledge, stakeholder power has not yet been analysed in the context of an MNC or, more specifically, in terms of CSR. Furthermore, this theoretical perspective contributes to decentring the firm from the conventional firm-stakeholder perspective and, as such, can contribute to enriching stakeholder theory (Berman and Johnson-Cramer, 2017) and be a further step towards building a more holistic framework for CSR strategizing.

The next section presents the theoretical background and is followed by the methodology section. The results of the case study are then presented and discussed, and four propositions are derived from the analysis of the findings. A final concluding section closes the article.

\section{Theoretical background}

To survive and be successful in the long term, companies must be able to deal with their stakeholders' environmental and social concerns (Goodman et al., 2017; Jakhar, 2017). Conversely, a good social performance is found to have a fairly strong association with market orientation (customer needs and expectations), while technology orientation is more of a hindrance (Ardito and Dangelico, 2018). CSR practices can be classified as internally oriented if they are developed within a firm or externally oriented if they require the involvement of external stakeholders, for example from the company's supply chain (Harms et al., 2013).

\section{Stakeholder theory: categories, influence, and strategies}

A stakeholder can be defined as "any group or individual who can affect or is affected by the achievement of the firm's objectives” (Freeman, 1984). Thus, stakeholder theory is concerned with uncovering and managing potential conflicts stemming from divergent interests (Frooman, 1999). Some studies refer to stakeholder engagement in a broad sense as being the positive interaction with, and/or involvement of, stakeholders in an organization's activities (Ayuso et al., 2014; Goodman et al., 2017).

Different categorizations of stakeholders have been proposed (e.g., Driessen and Hillebrand, 2013; Goodman et al., 2017; Wu et al., 2013). A recent study identifies stakeholders according to three axes: internal vs external, primary vs secondary, and domestic vs international - in addition to the regulatory stakeholders (Jakhar, 2017). External stakeholders include customers and suppliers as primaries, and rivals, NGOs, 
and the media as secondaries, while internal stakeholders are employees, shareholders, and financial institutions.

Freeman's seminal work considered stakeholder relationships to be dyadic, meaning that each stakeholder is only related to the firm and not to other stakeholders. In this regard, Mitchell et al. (1997) identifies urgency, legitimacy, and power as the three key attributes of stakeholder salience, i.e., the amount of attention a firm needs to give a stakeholder. Of these three attributes, power is the most widely recognised (Frooman, 1999) and has been categorised in several ways, including formal, economic and political (Freeman and Reed, 1983), coercive, utilitarian, and normative (Mitchell et al., 1997). Greater stakeholder power increases the chances of salience and therefore of influence, which may explain the heterogeneity in environmental/CSR performance that intrigues some authors (Delmas and Toffel, 2008; Goodman et al., 2017; Jahkar, 2017). Frooman (1999) proposes a descriptive model of stakeholder influence on a focal company business to explain how stakeholders attempt to influence the firm's decisionmaking and, ultimately, its behaviour. Building on resource dependence theory (Pfeffer and Salancik, 1978), Frooman focuses on how particular social players within the environment affect a local organization, assuming that the local organization can actively respond to them (Oliver, 1991). The model shows that the resource relationship determines which of the four types of influence strategies will be used by a stakeholder with a local firm: direct or indirect withholding (giving the resources or not), or direct or indirect usage (conditioning the use of resources). Direct strategies refer to the stakeholder's direct action on the firm, while indirect strategies refer to the use of another player - an ally - to act on a local firm (Frooman, 1999). In the model, the relationships are interdependent and multi-player (instead of dyadic), and indirect actions to influence firms are carried out through allies. That said, the model basically describes how a local firm is affected by its stakeholders and is therefore unidirectional (Goodstein and Wicks, 2007; Park and Choi, 2015).

\section{The role of power}

Power can be defined as the "structurally determined potential to obtain favoured payoffs - or access to resources - in relations where interests are opposed" (Willer et al., 1997). According to Emerson (1962), a resource is essentially anything a player perceives as valuable, whereas dependence is the state where one player relies on the actions of another to achieve specific outcomes (Frooman, 1999). This dependency 
approach to power has been applied at the intra-organizational level (Lachman, 1989), the inter-organizational level (Casciaro and Piskorski, 2005) and the interpersonal level (Brass and Burkhardt, 1993), and sometimes focuses specifically on an organization and its external stakeholders (Eesley and Lenox, 2006).

Based on Freeman's concept (1984), together with the resource dependence perspective, some research supports a positive link between the absolute (and unidirectional) power external stakeholders have over a firm and its consequent behaviour as regards its social performance. This reasoning relies on two premises (Tang and Tang, 2012): (i) corporate social performance rests on the relationships between a firm and its stakeholders (Agle et al. 1999); and (ii), most stakeholder concerns extend beyond the mere financial gains of the company (Campbell, 2007) and may represent a cost or investment.

There are also studies supporting the significant, positive influence that customer power and governments have on social performance (Agle et al., 1999; Studer et al., 2008), and Maignan and Ralston (2002) finds some stakeholders to be more influential than others.

However, firms should not be viewed as passive recipients of stakeholders' power (Tang and Tang, 2012) because a firm can also influence its stakeholders, which will, in turn, affect the terms of their transactions and eventually their profitability (Galbraith and Stiles, 1983). A firm can also utilize its power to reduce the power of communityor environmentally-focused stakeholders (Eesley and Lenox, 2006). Thus, according to Tang and Tang (2012), power should be viewed as a dyadic relationship, i.e., it is a property of the relationship between two parties rather than an attribute of either of them (Emerson, 1962; Ferrón Vilchez et al., 2017), and it is the result of the bidirectional interdependence between the two parties (Frooman, 1999). In this case, what is important is the net power balance between the two parties, which can be symmetrical if neither party has a power advantage over the other or asymmetrical when there is an imbalance (Casciaro and Piskorski, 2005) and one party can obtain better payoffs in the relationship. Accordingly, power-focused research underlines the importance of relative and not absolute power in relationships (Clement, 2005; Tang and Tang, 2012).

\section{Stakeholder power in MNCs}

MNCs manage a portfolio of businesses spread over different countries (Bartlett and Ghoshal, 2002) and therefore have complex internal structures that range from corporate 
(headquarters), to regional (several countries), and national (country subsidiary) to local levels (local subsidiary). Each of the levels identified is composed of individuals and groups (departments) who are internal stakeholders since they affect and are affected by the firm's objectives and actions (Freeman, 1984). For example, corporate departments may take decisions that affect regional, national, and local subsidiaries in any business area, for instance, CSR. The extent to which the decisions on one level affect the others depends on the distribution of power across the organization. Generally, the hierarchy reigns and more power (in quality or quantity) is attributed to the corporate level and less (in decreasing proportions) to the lower levels. Ultimately, power distribution depends on the degree of decentralization.

Thus, in the case of MNCs, every organization is under pressure from external and internal, domestic and international stakeholders (Goodman et al., 2017; Jakhar, 2017). The internal stakeholders in an MCN can be found on several levels - corporate, national, and local. In this case, the multiplicity of pressures from stakeholders underlines the importance the concept of stakeholder salience has and the attention a stakeholder is given from the focal organization. Since MNCs are essentially built on hierarchies which represent a distribution of power, stakeholder salience for internal stakeholders in MNCs is greatly determined by power, leaving urgency and legitimacy a to play a lesser role. The dominance of power is not as clear for external stakeholders and is more subject to the three elements of salience (Mitchell et al., 1997).

The different levels of MNCs (i.e., corporate, national, and local) enable the use of direct and indirect influencing strategies (Frooman, 1999), the latter for example being corporate policies that may reach the local level via the national level. Conversely, demands or claims from the local level may reach the corporate level via the national level. However, the power distribution in MNCs is mostly a corporate level decision and so the assignment of resources or not (withholding strategies) and the usage (conditioning) of resources (Frooman, 1999) are enforced by the hierarchical power system of the company.

Generally, within this MNC context a subsidiary is subject to both external and internal pressures and constraints, which introduces greater complexity in CSR decision-making than would otherwise be found in simpler organizations. This would also explain the variance found in the CSR performance of MNCs, a concern that has been raised by several authors (Delmas and Toffer, 2008; Jakhar, 2017). However, on the other hand, 
the power balance (Tang and Tang, 2012) among internal stakeholders at different levels is clarified because of the hierarchical power at the corporate level.

\section{Method}

We analysed a European multinational operating in the food and beverage industry and the case we studied refers to a subsidiary located in southern Europe. The organization was chosen as an exemplar case (Eisenhardt and Graebner, 2007; Yin, 2009) for exploring how an MNC subsidiary manages CSR activities under the pressures of their complex system of stakeholders. Because the case-study in question is an old, wellestablished, leading MNC it can probably be considered as a role model for peer MNCs or for other companies with the potential to become multinationals (Goodman et al., 2017). Therefore, this case has all the characteristics to be a powerful source for theory development (Welch et al., 2011). The company regards CSR as a driving force for creating long-term value for society, and consequently a source of competitive advantage. Information about the MNC has been limited here to preserve the anonymity the organization requested. However, to understand the methodology used in this research, some contextual information concerning the company has been provided.

The company was founded over 150 years ago and is now among the world's largest, most renowned food and beverage companies, with more than 100,000 employees and operations in more than 100 countries. It currently has ten (subsidiary) production centres in this country. These subsidiaries are renowned for their high performance, exporting $44 \%$ of their production to other countries. The subsidiary analysed in this paper was established in 1968 and has experienced enormous growth over the last few years to become the multinational's largest production plant for one of their main products. The multinational food and beverage company recently invested 37 million euros into this subsidiary which, in addition to expanding its production lines, means it can continuously recruit new employees to add to the 750-strong staff that currently work there.

A qualitative methodology based on the case study method is applied to analyse the relationship between the local organization and its stakeholders. This paper is based on a single case (Adderley and Mellor, 2014) analysed from the perspectives of different stakeholders (Dobele et al., 2014). Here, a case study is defined as an empirical approach that considers a phenomenon within its real-life context, where the boundaries between the phenomenon and the context are not manifested clearly and multiple 
sources of evidence are used (Yin, 2009). The single case study approach can provide a detailed understanding of situations, which may then be utilized inductively to create better theory (Yin, 2009; Welch et al., 2011). Single case studies are not intended to be generalizable but rather are utilized to gather information about the reality of the organization being studied (Eisenhardt, 1989; Eisenhardt and Graebner, 2007), thus constructing a "bridge" between theory and testing (Welch et al., 2011). We do not presume to theorize about these relationships (Weick, 1995) but rather to identify "gaps and holes” that have scarcely been analysed in the existing literature (Ridder, 2017). This approach is an ideal methodology when a holistic, in-depth investigation is required (Feagin et al., 1991). Given the complexity of understanding CSR, and the relationships between an MNC, their subsidiaries and stakeholders, the single case study enables the fundamental issues to be examined from multiple perspectives in an attempt to understand the complex system in question. Because of the limitations relying solely on the views of the case company under investigation has, the authors chose to interview a diverse variety of stakeholders who are also involved with the company in question.

This design is inspired by previous empirical work using single case studies to understand how and why things happen (Ridder, 2017) and as a way of analysing a phenomenon in greater depth (Fiss, 2009). Such an approach has already been employed to observe, for example, the development of a partnership between an NGO and a retail company (Adderley and Mellor, 2014); to examine changes and trends in kibbutz industries (Moskovich and Achouch, 2015); to analyse the success factors underlying inter-organizational partnerships in the university sports sector (Franco and Haase, 2017); to examine the importance Tripadvisor has on hotels' reputations (Nicoli and Papadopoulou, 2017); and to analyse the innovative production technologies used in low-tech sectors like the wood industry (Karagouni, 2018).

Multiple data sources were used (Yin, 2009) to reinforce the results obtained. Two major data sources were drawn on: (1) publicly available sources on the company website (i.e., descriptions of the business model and corporate sustainability in the annual reports) and (2) multiple interviews using a semi-structured questionnaire with six key internal and external informants. Data gathering was stopped when the point of saturation of information was reached (Glaser and Strauss, 1967). 
Four of the company's managers, each representing a different dimension of CSR, were interviewed: the human resources, purchasing, quality and environment, and finance managers.

This research used convergent in-depth interviewing (Carson et al., 2001), which is a series of interviews where the procedure is both structured and unstructured, thus enabling the researcher to develop, clarify, verify, and refine the core issues of the interview protocol. In the early stages, during which the interviewee tells a story about key events or episodes and what they learned from their experiences, the content of the interview is unstructured and flexible. The process then becomes more structured as the interviewer homes in on specific issues of the research problem (Carson et al., 2001).

The interviews in this paper were conducted between February 2012 and October 2014. The managers were interviewed up to three times each, and in the case of quality and environment, two managers were interviewed simultaneously. Two supplier companies (chosen by agreement with the company) were also interviewed to triangulate information and trace the possible impact the company's CSR practices have along the supply chain. Thus, our focus of analysis was upstream CSR practices which is centred on the production process (Schrempf-Stirling and Palazzo, 2016), i.e., the interviewees were the relevant stakeholders involved in the production steps (staff and suppliers). While interviewing more external stakeholders would have enriched the study, (the organization only agreed to provide information on these two), this approach did allow for the stakeholder and stakeholder power theories to be extended. Table 1 summarizes the main steps of the methodology.

The data analysis consisted of examining, categorizing, and recombining the evidence to address the main objective (Yin, 2009). This was done iteratively after each data collection step. The case study was jointly written by different members of the team to enrich data analysis (Ardito et al., 2019a; Eisenhardt, 1989). To comply with internal validity (Yin, 2009), once the case study had been written up with all the interviews included, it was sent to the local subsidiary to be reviewed by a management committee made up of two of the informants: a manager from the local subsidiary and a manager from the national headquarters. This revision improved the quality of the information used in this study. 
The revised case was codified by three of the four authors (Gioia et al., 2013). An open coding technique was used in the first stage of codification to identify all the stakeholders involved and the different levels of decision-making within the firm (Strauss and Corbin, 1998). These results were discussed by the authors and, in a second stage, the specific practices or activities involved in CSR were identified (Gioia et al., 2013; Goodman et al., 2017).

\section{Findings}

The findings from the in-depth interviews are presented below and the most important themes are then discussed. Following on from this, proposals for future research are presented. Excerpts from the in-depth interviews are used throughout to illustrate and provide context for the most relevant issues.

\section{Results of the case study}

The organization places its CSR practices under the concept of creating shared value for all stakeholders. Although practices in different CSR dimensions have been implemented (and are highlighted in the results), because of the kind of activity the organization is involved in, it is more focused on developing environmental practices. There are three levels of decision-making: corporate, country, and local. The results are presented following this hierarchy.

Most decisions are made at the corporate level (i.e., headquarters) as summarized in Table 2. While many of these aspects are directly implemented at all the levels by the company itself, it has gone one step further and involved employees in environmental management, thus helping them to become more environmentally responsible in their own day-to-day lives and creating a genuine environmental ethic. This is an example of indirect action (Frooman, 1999). A relevant motive for employees to engage in such actions is reciprocity, i.e., giving back to the company (Hahn, 2015), thus acknowledging the company as a behavioural prescriptor (Frooman, 1999).

(Table 2 here)

On the country level (i.e., national subsidiary), the organization transforms corporate policies into direct actions, which are then applied at the local level. Three main policies are implemented at this level: 
(1) Local purchasing and fair trade. The company buys high quality, km 0 raw materials which are environmentally friendly and comply with human rights and fair trade requirements. The company also aims to ensure that suppliers comply with sustainable practices by carrying out regular audits.

(2) Energy savings and water management are completely in line with corporate principles: 'The concern, shared by everyone, is saving water and, as such, there is a person in the department called 'general services' (a unit that manages the centre's energy sources and natural resources) dedicated to this and is responsible for complying with certain energy and water indicators' (HR manager)

Further, there are regular energy plans and studies to enhance energy and water savings and to improve energy efficiency in the factories. These practices are periodically shared with the different factories in the country via annual meetings to exchange good practices, and are complemented with a national program to train personnel in quality operational procedures to develop environmentally excellent products.

(3) The integrated management system (IMS), which is built on quality, environmental and occupational health and safety management systems (a positive CSR practice according to Glavopoulos et al., 2014), specifically defines the objectives, documentation, and processes.

At the local level (i.e., site-focused), the site applies the practices established on two other levels: 'From the corporate level we are only told to meet certain goals, to use an amount of water per cubic meter for the products. How we do it is then a plant decision. We have an environmental policy, which is the pillar that supports the management system, but of course this must be applied at the centre level. What is most important for us is the daily operational management of the system' (IMS manager).

Other practices implemented at this level but promoted at the corporate level are supplier policies and product life-cycle control. Regarding the former, a Suppliers Code has been created. As such, all commercial contracts have specific requirements about compliance with the business's corporate principles: 'We ask our suppliers to comply with these principles. If they want to work with us, they must comply with them. And to formalize this agreement, if the new version has been recently updated the contract will include these principles as well, but in older contracts a clause will be added where the 
suppliers accept the corporate principles about CSR. We have been doing this since 2012” (HR and Purchasing managers).

Regarding the second set of practices, the corporate level develops policies to monitor the product life-cycle, and especially the end phases, as a way of avoiding irresponsible uses: 'Nowadays the company pays attention to large supplies of the main raw materials needed. Companies with a large impact on the environment seek to have a lifetime warranty that covers aspects such as sustainability, the fight against child labour, etc.' (Purchasing manager). This control, however, is applied at the local level. The organisation's point of view is described by both the purchasing and the IMS managers: 'We require suppliers to be very strict. For example, some of our organic waste is sold to a waste-treatment company that ultimately sells it as fuel or as a fertilizer. We ask this company to tell us who it will sell the product to, where the client will use it and why it will be used because we do not want this organic waste appearing in a river nearby' (Purchasing manager). 'We hold regular meetings with external companies working here and we talk to them about environmental and safety issues. We work with a waste manager and they look directly for the different ends for the product. They inform us and we have to approve the new clients' proposals' (IMS manager).

From the supplier's point of view, this control is accepted. For example: 'We (the supplier) monitor the client, ensuring that they are not reselling the product or using it for their own profit. We observe the quantities and uses and check for coherency. The subsidiary does not supervise the control processes because the product is used for fuel. But every three months we check on the clients and visit the bigger ones. We know all of them' (Supplier 1).

However, a degree of autonomy is given to the local centre to implement some initiatives, for example training in environmental practices. The company is also responsible for strengthening environmentally-friendly mobility among employees: 'We are interested in people finding alternatives to the private vehicle and sharing cars. We provide public transport for the employees; we encourage the use of bicycles by providing parking spaces for them in the company' (IMS manager).

Last, employee involvement with IMS and communicating the environmental impact the company has and their control practices to employees and society is also the responsibility of the local centre: 'We want employees to not only be environmentally responsible when they are working, but also in their private lives. This attitude can also be taken into their homes' (IMS manager). 
At this level, all the actions are direct except for employee involvement and the training programs that go beyond the site boundaries, which are therefore indirect actions. Figure 1 structures a summary of the above-mentioned practices, accounting for the different levels (corporate, country, and local) and stakeholders, and internal or external power.

(Insert Figure 1 here)

\section{Discussion and propositions}

The following proposal aims to discuss the findings of the research and formalise them into a set of propositions.

Being part of an MNC makes a local subsidiary a party that is not only dependent on the power balance with the external stakeholders who have different priorities and means of allocating internal effort and resources (Adderley and Mellor, 2014; Pfeffer and Salancik, 1978), but is also dependent on the resources provided by them (country and corporate headquarters). Both types of stakeholder exert an influence and have power over the local subsidiary, thus influencing the subsidiary's behaviour. According to Varadarajan (2017), other factors, such as size, globalization, and reputation, can also influence the behaviour of a company. Larger and more globalized companies have a more sustainable orientation than smaller, less globalized companies. In addition, companies whose reputation can be damaged also have a greater propensity towards a more sustainable orientation as their activities can have a greater impact on their reputation and image.

At the internal level, our findings indicate that the power to decide the CSR strategy of the local subsidiary lies at the corporate level. As regards the adoption of the CSR strategy, the local company justifies this in moral terms as being a natural consequence of company (corporate) principles and values (Adderley and Mellor, 2014), and the result of the formal power (Freeman and Reed, 1983) that headquarters exert on the local subsidiary.

On the other hand, our case also illustrates how the local subsidiary is empowered not only to implement corporate-defined policies, but also to define some of its own policies to respond to local stakeholders and demands and gain local legitimacy (Goodman et al., 2017; Jakhar, 2007). In line with Kostova and Zaheer (1999), our findings indicate that a subsidiary is subject to pressure to maintain internal legitimacy 
within an MNC (Berman and Johnson-Cramer, 2017) and external legitimacy within its host institutional environment (Dobele et al., 2014). Thus, we pose the following proposition:

P1. Local subsidiaries are empowered by the corporate level to find a balance between corporate needs and the demands of the local environment.

Externally, the local subsidiary is basically affected by local stakeholders because global pressure from customers, governments, and NGOs is absorbed by the MNC (Adderley and Mellor, 2014; Goodman et al., 2017; Zhao et al., 2014), and the country headquarters, in turn, are the interlocutor for national dialogue and possible claims.

Despite the global pressures being indirect for the local subsidiary, they condition the CSR strategy that headquarters design to be complied with at all organizational levels, including the subsidiary level. In practice, headquarters use their internal power to diffuse their policies down to this level. This top-down approach helps the strategic implementation of CSR policies and enables CSR practices to be efficiently transmitted throughout the entire organization, as suggested by Muller (2006). Thus, the dependency argument within the organization (Lachman, 1989) applies in this case. In addition, it could be argued that the corporate level acts as an educator or legitimator stakeholder for the local subsidiary (Goodman et al., 2017). According to the former reasoning derived from the findings, we put forward the second proposition:

P2. Local subsidiaries implement the CSR policies defined at the corporate level in response to the demands exerted at the corporate level by global stakeholders.

The acceptance of global pressures and the corresponding CSR solutions, according to the results obtained, reduces the scope of external pressures on the local company since they can be dealt with centrally at the headquarters level, especially those from customers and some global suppliers. The remaining relevant stakeholders for the local subsidiary are then local governments (local community) and local suppliers. The power balance between these two stakeholders is rather different. With local suppliers, the subsidiary has a clear vantage position, for example it is unquestionable that local suppliers must accept the supplier's code of conduct within a reasonable time period. This supply chain pressure (Ardito et al., 2019b; Varadarajan, 2017) can be considered 
as a withholding strategy (Frooman, 1999) because the local subsidiary has the power to discontinue the contract if suppliers do not meet the requirements of the code. Another example is the product life-cycle control by which the local subsidiary ensures its ethical use. These actions are examples of how a MNC's responsibility spreads along the sector's value chain and how the CSR policies impact is leveraged or, to use Goodman et al. (2017)'s classification, how suppliers are ‘impact extenders’ of the CSR practices of the company. From the company's point of view and in line with the same classification, the organization analysed is the 'initiator' of the practice(s) to be spread. Accordingly, the third proposition is:

P3. Local subsidiaries can facilitate CSR diffusion along the value chain when they have power in the dyadic relationship through indirect action strategies.

The other main stakeholders are the local authorities. In this case, the power balance is less asymmetric, and this stakeholder has a better bargaining position with the local organization. Accordingly, the subsidiary we studied appeared to be more attentive to the requests of the local authorities, collaborating in local events with products or knowhow. The local subsidiary probably acknowledges the power local authorities have as being favourable to the subsidiary, its operations and externalities, and even its possible growth. Further, in the terms outlined by Goodman et al. (2017), local authorities could be considered as "context enablers" for CSR since they are responsible for regulations and policies and their reformulation to facilitate the subsidiary's operations and for defining the directions and limits of the MNC subsidiary's conduct.

Furthermore, local authorities seem to have a considerable amount of power, influence and interest, which could adversely affect the ability of the subsidiary or other stakeholders to pursue their goals or even block them entirely. In such circumstances, local subsidiaries would need to evaluate stakeholders' demands depending on the degree to which they wish to reach their goals while trying to balance these interests (Park and Choi, 2015). Thus, we propose:

P4. Local subsidiaries respond to external demands with different types of (withholding, usage) CSR actions depending on the power balance in the dyadic relationships. 
Figure 2 depicts the four propositions that have been presented within the same framework defined in Figure 1.

\author{
(Insert Figure 2 here)
}

\title{
Conclusions
}

With a focus on stakeholder power theory, the aim of this paper was to provide an answer to the research question of how and why internal and external stakeholders influence the CSR practices of a local subsidiary. To this effect, the paper addresses the issue of the balance between local, country, and corporate CSR, which is the outcome of internal and external stakeholder pressures and demands (Muller, 2006). According to the findings, the following conclusions can be drawn.

First, the local organization has three levels (corporate, country, and local) of CSR decision-making and policy implementation. Thus, a MNC's implementation of CSR involves the local level, balancing power and empowerment to build and maintain both internal and external legitimacy. This differentiation of levels contributes to the studies of Frooman (1999) and Zhao et al. (2014).

Second, CSR decisions and actions are implemented both directly by the company and indirectly through the stakeholders. To this effect, the organization mainly implements the direct policies emanating from the corporate level, albeit with some adaptations to the local level. Indirect actions, in turn, are exerted via local stakeholders. This case showed the multidirectionality of power pressures and actions taken regarding the environment (in line with Frooman, 1999; Tang and Tang, 2012). This is also related to the philosophy of the organization in question which, while based on its own values, is not closed off to external influences.

This organization diffuses good CSR practices based on stakeholder power (in line with Frooman, 1999 and Tang and Tang, 2012) and, at the same time, it aims to ensure that its activities do not impact negatively on any stakeholder. Its goal is to create shared value for all. This relationship is also nurtured by the stakeholders who compel the organization to perform better and help with the diffusion of CSR practices (Adderley and Mellor, 2014).

The theoretical implications of this case are based on the analysis of the reasons for the CSR behaviour of local subsidiaries who are willing to build their legitimacy with internal and external stakeholders at different levels. Previous research on CSR strategy 
and practice has not accounted for this complex system of stakeholder pressures or depicted a subsidiary as a party conditioned by both external and internal demands. On the other hand, previous research on stakeholder power has not addressed the particularities of subsidiaries in MNCs. Thus, the research that underlines the importance of stakeholder power is now better connected to the literature on CSR strategizing and implementation in MNCs.

Generally, this article highlights the importance of adapting to the environment (contextualization is important, as analysed in Welch et al., 2011), which can be linked to managerial implications. Managers at different decision-making levels can use these findings to better adopt and adapt their CSR strategies. For example, our results recommend that managers of local subsidiaries are aware of the distinct stakeholder pressures generated internally by the host country organization within the MNC and externally by other organizations and partners, and which may combine to create tensions between different alternative CSR actions or approaches. For example, according to the findings, a local manager is probably more likely to adopt CSR policies that award rights to external stakeholders from their local environment to gain local legitimacy. Such policies imply potential changes to organizational procedures, which need to be negotiated by the subsidiary's management with both the host country institution (Christmann, 2004) and the MNC upper hierarchical levels.

The main limitation of this study is its focus on a single case, although the analysis does consider several players and decision-making levels (Dobele et al., 2014), thus contributing to deepening the analysis of stakeholder power theory in MNCs. The results and conclusions, however, cannot be extrapolated to any population (Piekkari et al., 2009) and so should be tested further. This paper is an inductive case (Welch et al., 2011) designed to present a case study that exemplifies a gap found in the literature (Ridder, 2017) i.e., the analysis of power relationships in the context of a MNC. Although this paper is an approach to this organizational phenomenon (Weick, 1995), future research should test the propositions presented to identify patterns and the role of context in this type of relationship (Welch et al., 2011) which will, in turn, further contribute to the theory-building process (Weick, 1995).

\section{References}

Adderley, S. and Mellor, D. (2014), “Who’s influencing whom? Developing sustainable business partnerships”, EuroMed Journal of Business, Vol. 9, No., 1, pp. 60-74. 
Agle, B.R., Mitchell, R.K. and Sonnenfeld, J.A. (1999), "Who matters to CEOS? An investigation of stakeholder attributes and salience, corporate performance, and CEO values”, Academy of Management Journal, Vol. 42, No. 5, pp. 507-525.

Ardito, L. and Dangelico, M. R. (2018), “Firm Environmental Performance under Scrutiny: The Role of Strategic and Organizational Orientations”, Corporate Social Responsibility and Environmental Management, Vol. 25, pp. 426-440.

Ardito, L., Ferraris, A., Messeni Petruzzelli, A., Bresciani, S. and Del Giudice, M. (2019a), “The role of universities in the knowledge management of smart city projects", Technological Forecasting and Social Change, Vol. 142, pp. 312-321.

Ardito, L., Messeni Petruzzelli, A., Dezi, L. and Castellano, S. (2019b), “The influence of inbound open innovation on ambidexterity performance: Does it pay to source knowledge from supply chain stakeholders?”, Journal of Business Research, https://doi.org/10.1016/j.jbusres.2018.12.043

Ayuso S., Rodriguez M.A., García-Castro, R. and Ariño, M. (2014), "Maximizing stakeholders' interests: An empirical analysis of the stakeholder approach to corporate governance”, Business and Society, Vol. 53, No. 3, pp. 414-439.

Barin Cruz, L. and Boehe, D.M. (2010), "How do leading retail MNCs leverage CSR globally? Insights from Brazil”, Journal of Business Ethics, Vol. 91, pp. 243-263.

Bartlett, C.A. and Ghoshal. S. (2002), Managing across borders: The transnational solution, Harvard Business Press.

Berman, S.L. and Johnson-Cramer, M.E. (2017), “Stakeholder Theory Seeing the Field Through the Forest”, Business and Society, doi: https://doi.org/10.1177/0007650316680039

Birkinshaw, J. (1998), “Corporate entrepreneurship in network organizations: How subsidiary initiative drives internal market efficiency”, European Management Journal, Vol. 16, No. 3, pp. 355-364.

Bondy, K. and Starkey, K. (2014), “The dilemmas of internationalization: corporate social responsibility in the multinational Corporation”, British Journal of Management, Vol. 25, No. 1, pp. 4-22.

Brass, D.J. and Burkhardt, M.E. (1993), "Potential power and power use: An investigation of structure and behavior”, Academy of Management Journal, Vol. 36, No. 3, pp. 441-470. 
Campbell, J.L. (2007), "Why would corporations behave in socially responsible ways? An institutional theory of corporate social responsibility", Academy of Management Review, Vol. 32, No. 3, pp. 946-967.

Campbell, J.T., Eden, L. and Miller, S.R. (2012), “Multinationals and corporate social responsibility in host countries: Does distance matter?”, Journal of International Business Studies, Vol. 43, No. 1, pp. 84-106.

Carson, D., Gilmore, A., Perry, C. and Gronhaug, K. (2001), Qualitative Marketing Research, Sage, London.

Casciaro, T. and Piskorski, M.J. (2005), "Power imbalance, mutual dependence, and constraint absorption: A closer look at resource dependence theory”, Administrative Science Quarterly, Vol. 50, No. 2, pp. 167-199.

Chatzoglou, P., Chatzoudes, D., Amarantou, V. and Aggelidis, V. (2017), “Examining the antecedents and the effects of CSR implementation: an explanatory study”, EuroMed Journal of Business, Vol. 12, No. 2, pp. 189-206.

Christmann, P. (2004), "Multinational companies and the natural environment: Determinants of global environmental policy standardization”, Academy of Management Journal, Vol. 47, No.5, pp. 747-760.

Clement, R.W. (2005), “The lessons from stakeholder theory for US business leaders”, Business Horizons, Vol. 48, No. 3, pp. 255-264.

Commission of the European Communities (2001), Promoting a European Framework for Corporate Social Responsibilities, COM (2001) 366 final, Brussels.

Dahlsrud, A. (2008), "How corporate social responsibility is defined: an analysis of 37 definitions”, Corporate Social Responsibility and Environmental Management, Vol. 15, No. 1, pp. 1-13.

Delmas, M.A. and Toffel, M.W. (2008), “Organizational responses to environmental demands: opening the black box”, Strategic Management Journal, Vol. 29, No. 10, pp. 1027-1055.

Di Bella, V. and Al-Fayoumi, N. (2016), "Perception of stakeholders on corporate social responsibility of Islamic Banks in Jordan”, EuroMed Journal of Business, Vol. 11, No. 1, pp. 30-56.

Dobele, A.R., Westberg, K., Steel, M. and Flowers, K. (2014), “An Examination of Corporate Social Responsibility Implementation and Stakeholder Engagement: A Case Study in the Australian Mining Industry”, Business Strategy and the Environment, Vol. 23, pp. 145-159. 
Driessen, P. H. and Hillebrand, B. (2013), “Integrating multiple stakeholder issues in new product development: an exploration”, Journal of Product Innovation Management, Vol. 30, No., pp. 364-379.

Eesley, C. and Lenox, M.J. (2006), “Firm responses to secondary stakeholder action”, Strategic Management Journal, Vol. 27, No. 8, pp. 765-781.

Eisenhardt, K. M. (1989), “Building Theories from Case Study Research”, The Academy of Management Review, Vol. 14, pp. 532-550.

Eisenhardt, K. M. and Graebner, M. E. (2007), "Theory building from cases: Opportunities and challenges”, Academy of Management Journal, Vol. 50, No. 1, pp. 25-32.

Emerson, R.M. (1962), “Power-dependence relations”, American Sociological Review, Vol. 27, No. 1, pp. 31-41.

Feagin, J. R., Orum, A. M. and Sjoberg, G. (Eds.). (1991). A case for the case study. UNC Press Books.

Ferrón Vilchez, V., Darnall, N. and Aragón Correa, J.A. (2017), "Stakeholder influences on the design of firms' environmental practices”, Journal of Cleaner Production, Vol. 142, pp. 3370-3381

Fiss, P.C. (2009), “Case studies and the configurational analysis of organizational phenomena”. in Byrne, D.S. and. Ragin, C.C (Ed.), The SAGE handbook of case-based methods, Thousand Oaks: SAGE, London,pp. 424-440..

Franco, M. and Haase, H. (2017), "Success factors in university sport partnerships: a case study”, EuroMed Journal of Business, Vol. 12, No. 1, pp.87-102

Freeman, R.E. (1984), Strategic Management: A Stakeholder Approach. Pitman: Boston.

Freeman, R. E. and Reed, D.L. (1983), "Stockholders and stakeholders: A new perspective on corporate governance”, California Management Review, Vol. 25, No. 3, pp. 88-106.

Frooman, J. (1999), “Stakeholder influence strategies”, Academy of Management Review, Vol. 24, No. 2, pp. 191-205.

Galbraith, C.S. and Stiles, C.H. (1983), "Firm profitability and relative firm power”, Strategic Management Journal, Vol. 4, No. 3, pp. 237-249.

Gifford, B., Kestler, A. and Anand, S. (2010), “Building local legitimacy into corporate social responsibility: Gold mining firms in developing nation”, Journal of World Business, Vol. 45, No. 3, pp. 304-311. 
Gioia, D.A., Corley, K.G. and Hamilton A.L. (2013), “Seeking qualitative rigor in inductive research: notes on the Gioia methodology”, Organizational Research Methods, Vol. 16, No. 1, pp. 15-31.

Glaser, B.G. and Strauss, A.L. (1967), Discovery of grounded theory: Strategies for qualitative research. Chicago: Aldine.

Glavopoulos, E., Bersimis, S., Georgakellos, D. and Sfakianakis, M. (2014), “Investigating the factors affecting companies' attitudes towards CSR and CER during the fiscal crisis in Greece”, Journal of Environmental Planning and Management, Vol. 57, No. 11, pp. 1612-1641.

Goodman, J., Korsunova, A. and Halme, M. (2017), "Our Collaborative Future: Activities and Roles of Stakeholders in Sustainability-Oriented Innovation”, Business Strategy and the Environment, Vol. 26, pp. 731-753.

Goodstein, J.D. and Wicks, A.C. (2007), “Corporate and stakeholder responsibility: Making business ethics a two-way conversation”, Business Ethics Quarterly, Vol. 17, No. 3, pp. 375-398.

Hahn, T. (2015), "Reciprocal stakeholder behavior: A motive-based approach to the implementation of normative stakeholder demands”, Business \& Society, Vol. 54, No. 1, pp. 9-51.

Hah, K. and Freeman, S. (2014), "Multinational enterprise subsidiaries and their CSR: A conceptual framework of the management of CSR in smaller emerging economies”, Journal of Business Ethics, Vol. 122, No. 1, pp. 125-136.

Harms, D., Hansen, E.G. and Schaltegger, S. (2013), "Strategies in Sustainable Supply Chain Management: An Empirical Investigation of Large German Companies”, Corporate Social Responsibility and Environmental Management, Vol. 20, No. 4, pp. 205-218.

Jakhar, S. K. (2017), “Stakeholder Engagement and Environmental Practice Adoption: The Mediating Role of Process Management Practices”, Sustainable Development, Vol. 25, pp. 92-110.

Jamali, D. (2010), “The CSR of MNC Subsidiaries in Developing Countries: Global, Local, Substantive or Diluted?”, Journal of Business Ethics, Vol. 93, pp. 181-200.

Jones, P., Comfort, D. and Hillier, D. (2007), “Corporate social responsibility: a case study of the top ten global retailers”, EuroMed Journal of Business, Vol. 2, No. 1, pp.23-35. 
Karagouni, G. (2018), “Production technologies and low-technology knowledgeintensive venturing”, EuroMed Journal of Business, Vol. 13, No. 1, pp.75-85.

Kostova, T. and Zaheer, S. (1999), “Organizational legitimacy under conditions of complexity: The case of the multinational Enterprise”, Academy of Management Review, Vol. 24, No. 1, pp. 64-81.

Lachman, R. (1989), "Power from what? A reexamination of its relationships with structural conditions”, Administrative Science Quarterly, Vol. 34, No. 2, pp. 231-251.

Maignan, I. and Ralston, D.A. (2002), “Corporate social responsibility in Europe and the US: Insights from businesses’ self-presentations”, Journal of International Business Studies, Vol. 33, No. 3, pp. 497-514.

Mitchell, R.K., Agle, B.R. and Wood, D.J. (1997), “Toward a theory of stakeholder identification and salience: Defining the principle of who and what really counts”, Academy of Management Review, Vol. 22, No. 4, pp. 853-886.

Mohammed, M. (2013), “Corporate accountability in the context of sustainability-a conceptual framework”, EuroMed Journal of Business, Vol. 8, No..3, pp. 243-254.

Moskovich, Y. and Achouch, Y. (2015), "Metamorphosis of a kibbutz industry: an Israeli case study”, EuroMed Journal of Business, Vol. 10, No. 2, pp. 181-197.

Muller, A. (2006), “Global Versus Local CSR Strategies”, European Management Journal, Vol. 24, No. 2-3, pp. 189-198.

Nicoli, N. and Papadopoulou, E. (2017), “TripAdvisor and reputation: a case study of the hotel industry in Cyprus”, EuroMed Journal of Business, Vol. 12, No. 3, pp. 316334.

Oliver, C. (1991), “Strategic responses to institutional processes”, Academy of Management Review, Vol. 16, pp. 145-179.

Park, B.I. and Choi, J. (2015), "Stakeholder Influence on Local Corporate Social Responsibility Activities of Korean Multinational Enterprise Subsidiaries”, Emerging Markets Finance and Trade, Vol. 51, No. 2, pp. 335-350.

Pfeffer, J. and Salancik, G.R. (1978), The external control of organizations. A resource dependence perspective, Stanford University Press: Stanford, CA.

Piekkari, R., Welch, C. and Paavilainen, E. (2009), “The case study as disciplinary convention: Evidence from international business journals”, Organizational Research Methods, Vol. 12, No. 3, pp. 567-589.

Ridder, H.G. (2017), “The theory contribution of case study research designs”, Business Research, Vol. 10, No. 2, pp. 281-305. 
Rodríguez Bolívar, M. P., Garde Sánchez, R. and López Hernández, A. M. (2015), "Managers as drivers of CSR in state-owned enterprises", Journal of Environmental Planning and Management, Vol. 58, No. 5, pp. 777-801.

Salehi, M., Lari, M. and Khorashadizadeh, S. (2018), “Corporate social responsibility and future financial performance: Evidence from Tehran Stock Exchange”, EuroMed Journal of Business, Vol. 13, No. 3, pp. 351-371.

Shams, S.M.R. (2016), "Branding destination image: A stakeholder causal scope analysis for internationalisation of destinations", Tourism Planning \& Development, Vol. 13, No. 2, pp. 140153.

Schrempf-Stirling, J. and Palazzo, G. (2016), “Upstream corporate social responsibility: The evolution from contract responsibility to full producer responsibility”, Business \& Society, Vol. 55, No. 4, pp. 491-527.

Strauss, A. and Corbin, J.M. (1998), Basics of Qualitative Research: Techniques and Procedures for Developing Grounded Theory, 2nd Edition, Thousand Oaks, CA: Sage.

Studer, S., Tsang, S., Welford, R. and Hills, P. (2008), "SMEs and voluntary environmental initiatives: a study of stakeholders' perspectives in Hong Kong”, Journal of Environmental Planning and Management, Vol. 51, No. 2, pp. 285-301.

Surroca, J., Tribó, J.A. and Zahra, S.A. (2013), “Stakeholder pressure on MNEs and the transfer of socially irresponsible practices to subsidiaries”, Academy of Management Journal, Vol. 56, No. 2, pp. 549-572.

Tang, Z. and Tang, J. (2012), “Stakeholder-firm power difference, stakeholders' CSR orientation, and SMEs' environmental performance in China”, Journal of Business Venturing, Vol. 27, No. 4, pp. 436-455.

van Alstine, J. (2009), “Governance from Below: Contesting Corporate Environmentalism in Durban, South Africa”, Business Strategy and the Environment, Vol. 18, No. 2, pp. 108-121.

Varadarajan, R. (2017), “Innovating for sustainability: a framework for sustainable innovations and a model of sustainable innovations orientation", Journal of the Academy of Marketing Science, Vol. 45, No. 1, pp. 14-36.

Weick, K.E. (1995), "What theory is not, theorizing is”, Administrative Science Quarterly, Vol. 40, pp. 385-390.

Welch, C., R. Piekkari, E. Plakoyiannaki, and Paavilainen-Mäntymäki. E. (2011), "Theorising from case studies: towards a pluralist future for international business research”, Journal of International Business Studies, Vol. 42, pp. 740-762. 
Willer, D., Lovaglia, MJ. and Markovsky, B. (1997), "Power and influence: A theoretical bridge”, Social Forces, Vol. 76, No. 2, pp. 571-603.

Wu, Q., He, Q., and Duan, Y. (2013), “Explicating dynamic capabilities for corporate sustainability”. EuroMed Journal of Business, Vol. 8, No. 3, pp. 255-272.

Yin, R.K. (2009), Case Study Research: Design and Methods, 4th ed. Sage Publications: Thousand Oaks, CA

Zhao, M., Park, S. H. and Ahou, N. (2014), "MNC strategy and social adaptation in emerging markets”, Journal of International Business Studies, Vol. 45, pp. 842 - 861. 